\title{
Capripoxviruses: An Emerging Worldwide Threat to Sheep, Goats and Cattle
}

\author{
S. Babiuk ${ }^{1,2}$, T. R. Bowden ${ }^{3}$, D. B. Boyle ${ }^{3}$, D. B. Wallace ${ }^{4,5}$ and R. P. Kitching ${ }^{1}$ \\ ${ }^{1}$ National Centre for Foreign Animal Disease, Winnipeg MB, Canada \\ 2 University of Manitoba, Department of Immunology, Winnipeg MB, Canada \\ ${ }^{3}$ CSIRO Livestock Industries, Australian Animal Health Laboratory, Geelong, Vic., \\ Australia \\ ${ }^{4}$ Biotechnology Division, Onderstepoort Veterinary Institute, Onderstepoort, South \\ Africa \\ ${ }^{5}$ University of Pretoria, Department of Veterinary Tropical Diseases, Faculty of \\ Veterinary Science, Onderstepoort, South Africa
}

Correspondence to S. Babiuk. National Centre for Foreign Animal Disease, 1015 Arlington Street, Winnipeg MB, R3E 3M4 Canada. Tel.: +1-204-784-5956; Fax: +1-204789-2038; E-mail: babiuks@inspection.gc.ca

\section{Abstract}

Capripoxviruses are the cause of sheeppox, goatpox and lumpy skin disease (LSD) of cattle. These diseases are of great economic significance to farmers in regions in which they are endemic and are a major constraint to international trade in livestock and their products. Although the distribution of capripoxviruses is considerably reduced from what it was even 50 years ago, they are now expanding their territory, with recent outbreaks of sheeppox or goatpox in Vietnam, Mongolia and Greece, and outbreaks of LSD in Ethiopia, Egypt and Israel. Increased legal and illegal trade in live animals provides the potential for further spread, with, for instance, the possibility of LSD becoming firmly established in Asia. This review briefly summarizes what is known about capripoxviruses, including their impact on livestock production, their geographic range, host-specificity, clinical disease, transmission and genomics, and considers current developments in diagnostic tests and vaccines. Capripoxviruses have the potential to become emerging disease threats because of global climate change and changes in patterns of trade in animals and animal products. They also could be used as economic bioterrorism agents. 


\section{Introduction}

The three species in the genus Capripoxvirus, subfamily Chordopoxvirinae, family Poxviridae, are sheeppox virus (SPPV), goatpox virus (GTPV), and lumpy skin disease virus (LSDV) of cattle (Buller et al., 2005; Diallo and Viljoen, 2007). Capripoxviruses are difficult to distinguish morphologically from orthopoxviruses and their DNA genomes have much in common, including the closed hairpin loops at their termini (Damon, 2007). The cellular receptors for poxvirus entry are currently unknown (Moss, 2006), but the functions of some of the virus-coded proteins have been demonstrated, including some involved in evasion of the host immune response (Moss and Shisler, 2001). The most striking similarity between different poxviruses is the clinical disease which they induce, characterized by pox lesions in the skin.

\section{Impact on Production}

Sheeppox and goatpox in endemic areas are associated with significant production losses because of reduced milk yield, decreased weight gain, increased abortion rates, damage to wool and hides, and increased susceptibility to pneumonia and fly strike, while also being a direct cause of mortality (Yeruham et al., 2007). Morbidity and mortality rates can be very high, approaching $100 \%$ in naïve animals (reviewed in Bhanuprakash et al., 2006). For example, it was calculated that it took 6 years for a flock in India to recover from an outbreak in which the mortality rate had been $49.5 \%$ (Garner et al., 2000). In contrast, LSDV is an occasionally fatal disease of cattle with morbidity averaging $10 \%$ and mortality $1 \%$ in affected herds, although mortality rates over $75 \%$ have been recorded (Diesel, 1949). Production losses are similar to sheeppox and goatpox with decreased weight gain, reduced milk production and damage to hides. The reasons for the wide ranges in mortality following infection with LSDV are currently unknown but could be attributed to numerous factors that include the cattle breed, virus isolate, secondary bacterial infections, state of health of the animal, as well as the type of insect vector involved in transmission. Another factor is the confusion between LSD and pseudo-LSD caused by the herpes virus, Allerton virus (reviewed by Hunter and Wallace, 2001). In countries for which capripoxviruses are exotic, the economic costs because of disease eradication and trade restrictions would be substantial and comparable to foot and mouth disease outbreaks (Garner and Lack, 1995; De Clercq and Goris, 2004). New outbreaks of sheeppox, goatpox and LSD in previously free regions are immediately notifiable diseases under the World Organization for Animal Health (OIE) guidelines. In addition, capripoxviruses are listed by the United States Department of Agriculture Select Agents legislation as potential economic bioterrorism agents and are on the National Select Agent Registry. Sheeppox, goatpox and LSD are globally the most serious poxvirus diseases of production animals (Carn, 1993), although camelpox is locally a severe disease.

Diseases caused by the capripoxviruses are transboundary being significant impediments to trade in livestock and livestock products. This particularly affects the economic well- 
being of farmers in developing countries and would have substantial economic impacts on industrialized countries should the diseases be introduced to them.

\section{Geographic Range}

There are distinct differences between the geographic distribution of sheeppox, goatpox and LSD viruses. The geographic range of sheeppox and goatpox (Fig. 1a) has been restricted in the last 50 years mainly to Asia and Africa, extending from Africa north of the Equator (Asagba and Nawathe, 1981; Kitching et al., 1989; Mariner et al., 1991; Achour and Bouguedour, 1999), into the Middle East (Daoud, 1997), Turkey (Oğuzoğlu et al., 2006), and Asia including regions of the former Soviet Union (Orlova et al., 2006), India (Mondal et al., 2004; Bhanuprakash et al., 2005) and China (Zheng et al., 2007). Sheeppox or goatpox extended their range into Bangladesh in 1984 (Kitching et al., 1987b) and more recently into Vietnam (2005 and 2008) and Mongolia (2006 and 2007) in the east, and repeated incursions have been reported in Greece in southern Europe (2007) (World Animal Health Information Database, OIE).
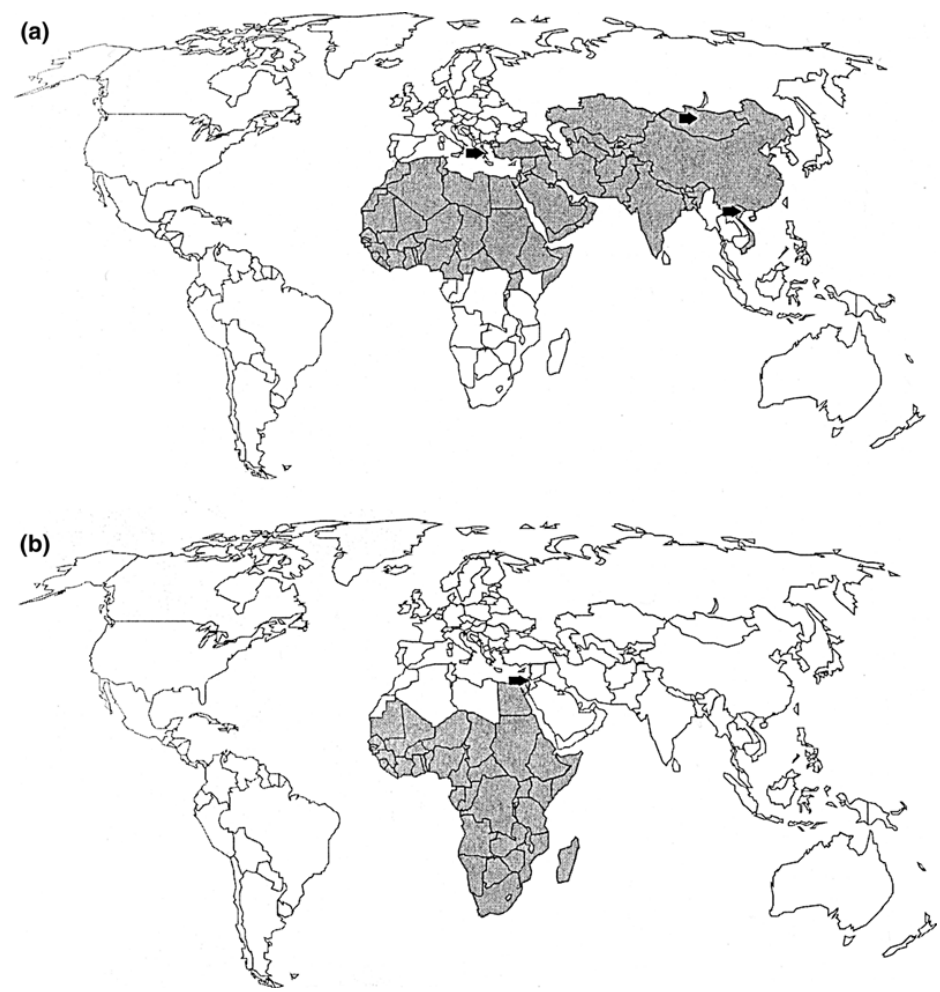

Fig. 1. Map showing likely global distribution of sheeppox and goatpox (a) and LSD (b) viruses. Recent outbreaks are marked with arrows. 
In contrast, LSDV was first identified in 1929 originating in sub-Saharan Africa from where it has spread north and south during the past 70 years (Woods, 1988). The endemic geographic range of LSDV (Fig. 1b) is currently limited to the continent of Africa (including Madagascar), although recent outbreaks in Egypt (House et al., 1990) spread into Israel (Yeruham et al., 1995). An additional outbreak of LSD occurred in Egypt in 2006, having been introduced with foot and mouth disease by cattle imported from Ethiopia, and spread to Israel (World Animal Health Information Database, OIE) creating a real risk of LSDV establishing itself in the Middle East and spreading into Asia and Europe (Kitching and Carn, 2004).

The origin of LSDV has remained a mystery ever since it was first identified in a geographic region free of sheeppox and goatpox viruses. It is also difficult to explain why sheeppox and goatpox viruses have not spread south of the Equator as did LSD. It is possible that the ability of LSDV to provide heterologous cross-protection against sheeppox and goatpox is one possible factor limiting the spread of these diseases southwards (see below), although this is not consistent with the co-existence of LSD, sheeppox and goatpox in countries in equatorial Africa such as Kenya.

The spread of capripoxvirus into new areas is predominantly associated with the increase of illegal animal movement through trade (Domenech et al., 2006) as well as inadequate or breakdown of veterinary services (Rweyemamu et al., 2000). Countries free of capripoxvirus usually have in place legislation based on OIE recommendations that attempt to prevent the trans-boundary spread of production-limiting diseases, but increasingly these are becoming more difficult to enforce, including on the border of the European Union. Biting flies have also been implicated in the spread of capripoxviruses, as was the case during the outbreak of LSD in Israel in 1989 (Yeruham et al., 1995). Capripoxviruses are not present in north, central or south America, south east Asia (excluding Vietnam) or Australasia.

The impacts of global climate change on insect vectors, established as a route of transmission for LSD and speculated as possible for sheeppox and goatpox viruses (because of very high viral loads in the skin), suggest that there are real risks of further spread of these diseases into other geographic regions.

\section{Host-specificity}

Capripoxviruses only infect some ruminant species and have a tropism for certain cell types (McFadden, 2005); they are not infectious to humans (Regnery, 2007). Sheeppox virus and GTPV cause clinical disease in sheep and goats, respectively; however, there is a wide range of clinical disease seen with different field isolates. The nomenclature is largely made up of the location (country) and the species from which it has been isolated (sheep or goat or sheep and goat). This issue of naming strains sheeppox, goatpox or sheep and goat pox remains problematic since this has been based on field observation of the species affected whether sheep or goats. There is little else to support the species strain designation except when the viruses are used to experimentally infect both hosts 
under controlled conditions. Given the large size of the viruses and the complexity of encoded factors likely to determine host-specificity, currently there are no molecular criteria upon which to base strain (sheep or goat or sheep and goat) designation. Some isolates are uniformly pathogenic in both sheep and goats such as some capripoxvirus strains from Kenya (Davies, 1976) and the Middle East (Kitching et al., 1986). Most isolates, however, cause more severe disease in either sheep or goats and only mild or sub-clinical infection in the other species. It is unknown whether closely related North American species such as mountain goats and mountain sheep would be susceptible to GTPV or SPPV, but it is likely they would exhibit at least some degree of susceptibility. In contrast, LSDV with a few exceptions only causes clinical disease in cattle. It has been demonstrated that LSDV can experimentally infect other closely related game animals such as the giraffe and impala (Young et al., 1970) and infection has been reported in an Arabian oryx (Greth et al., 1992a). However, there have not been any confirmed outbreaks of clinical disease in the field in any wildlife species. An extensive serological study involving a wide range of African wildlife demonstrated a low percentage (between $1-10 \%$ ) of giraffe, impala, springbok, kudu, waterbuck and reedbuck had capripoxvirus virus neutralization activity with African buffalo and wildebeest being negative (Hedger and Hamblin, 1983), although in an earlier study by Davies (1982) antibody levels were detected in buffalo. Two of 239 serum samples from Arabian oryx had antibodies reactive to LSDV (Greth et al., 1992b). These studies suggest that wildlife species do not play a significant role in the spread or maintenance of LSDV and there is currently no strong evidence of a wildlife reservoir for capripoxviruses. However, wildlife infected with LSDV could be at a distinct disadvantage for survival, and their potential involvement remains unknown since the high rate of removal of infected animals by death and predation would result in a low seropositivity rate in the remaining population. Molecular markers for host- specificity have not been well characterized. However, recent studies suggest that analysis of sufficient virus strains and genes might reveal insights into and markers for host-specificity of capripoxviruses (Hosamani et al., 2004).

\section{Clinical Disease and Pathogenesis}

Following the introduction of sheeppox and goatpox viruses into susceptible animals, fever develops concurrently with the generation of macules in the skin. Rhinitis, conjunctivitis and excessive salivation also occur following infection. Macules enlarge and develop into papules and then scabs. The distribution of pox lesions in the skin can be widespread with over $50 \%$ of the skin surface affected. However, more commonly in enzootic areas, the lesions are restricted to a few nodules under the tail and are thus only detected on close examination. Quantitative analysis using virus isolation and real-time PCR of the pathogenesis of SPPV and GTPV in their respective hosts revealed high viral loads in skin (Bowden et al., 2008). Internal organs such as the lung and stomach also develop characteristic pox-like lesions. Draining lymph nodes are often enlarged following infection; however, lymphadenopathy is not associated with high viral replication/load in the nodes (Bowden et al., 2008). In severely affected animals, respiratory distress occurs, followed by death. Like smallpox, capripoxvirus disease pathogenesis is associated with both viral and host factors (Stanford et al., 2007). The 
control of virus replication by the host likely determines the clinical outcome. Viremia, likely cell-associated (Kitching and Taylor, 1985), also starts at the time of lesion occurrence and lasts until the time of seroconversion when host antibodies can neutralize the virus.

Lumpy skin disease in cattle can range from acute to sub-clinical. Certain breeds of cattle are more susceptible than others, especially those that are thin-skinned such as Jersey and Guernsey breeds, and African Sanga cattle such as the Fogera in Ethiopia (Peter Roeder, personal communication). The most obvious clinical sign of LSD is the formation of skin lesions that can cover the entire body (Davies, 1991). Once these skin lesions heal, they leave scars that permanently damage the hide. The disease is characterized by pyrexia, lymphadenopathy and skin nodules that progress to sitfasts, which can persist for many months. The morbidity rate in natural infection varies dramatically from $3 \%$ to $85 \%$ indicating that a combination of factors is likely to influence clinical disease progression (Woods, 1988). Not all cattle exhibit clinical signs following experimental infection with LSDV (Carn and Kitching, 1995a). This is in contrast to SPPV and GTPV for which a much more uniform range of responses is exhibited following experimental infection in the respective host species. Nevertheless, different virus isolates can exhibit a wide range of clinical signs ranging from mild to severe. Like sheeppox and goatpox viruses, LSDV has a tropism for epithelial cells (Davies, 1991).

\section{Transmission}

Sheeppox and goatpox viruses are highly contagious and spread through aerosols and/or close contact with infected animals and by indirect means such as contamination of cuts and abrasions (Kitching and Carn, 2004). Viral shedding occurs in nasal, oral and conjunctival secretions starting from the appearance of papules, with the quantity and duration of shedding dependent on the virus isolate and host species (Bowden et al., 2008). Viral DNA and infectious virions can be detected in some secretions for up to a month following resolution of acute disease (Bowden et al., 2008). Virus can remain viable in scabs for months in the environment, and it is likely that the viral A type inclusion body protein in infected cells may be important in protecting the virion after the scab has disintegrated, although this has not yet been proven. The amount of viral shedding correlates with the severity of clinical disease, with sheep and goats displaying mild clinical signs shedding less virus than sheep and goats that have more severe clinical disease. The high concentrations of virus in the skin may also contribute to the spread of sheeppox and goatpox via insect vectors (Bowden et al., 2008). There are sufficient precedents for this proposition with myxoma virus (Fenner et al., 1952), fowlpox virus (Damon, 2007) and LSDV (Chihota et al., 2001, 2003; Mellor et al., 1987) being transmitted mechanically by biting insects.

In contrast to sheeppox and goatpox viruses, LSDV appears mainly to be spread mechanically by biting insects (Chihota et al., 2001, 2003; Mellor et al., 1987) with transmission by direct contact between animals being insignificant. Under experimental conditions, it was demonstrated that no disease transmission, nor immunity, was 
generated in naïve animals housed with infected animals in the absence of suitable insect vectors (Carn and Kitching, 1995b). Animals that did not show clinical signs did not shed virus in oral, nasal or conjunctival swabs (Carn and Kitching, 1995a). LSDV can be isolated in the semen from infected animals for extended periods of time (Irons et al., 2005; Osuagwuh et al., 2007), and transmission may occur by this route.

\section{Genomics of Capripoxviruses}

Capripoxviruses are double-stranded DNA viruses with genomes approximately $150 \mathrm{kbp}$ in size. Goatpox and sheeppox viruses share at least 147 putative genes (Tulman et al., 2002). Lumpy skin disease virus has an additional nine genes that are non-functional in sheeppox and goatpox viruses, some of which are likely responsible for their ability to infect cattle (Tulman et al., 2001). Capripoxvirus isolates are extremely conserved with genome identities of at least $96 \%$ between SPPV, GTPV and LSDV (Tulman et al., 2002). A comparative study of the genomes of two field isolates of LSDV with the genome of the South African Onderstepoort vaccine strain suggests that capripoxvirus virulence is linked to a number of genes putatively involved in host immuno-modulation (Kara et al., 2003). Phylogenetic analysis of the capripoxvirus intracellular mature virion envelope protein P32 nucleotide sequence data revealed that SPPV, GTPV and LSDV clustered into host species-specific groups (Hosamani et al., 2004); however, more data on different gene sequences from additional virus isolates are needed to confirm this observation. Further genomic studies are essential to fully understand the determinants of capripoxvirus virulence, host- specificity and geographic distribution. Further comparative genomic studies between SPPV, GTPV and LSDV would also answer the question of the degree of species-specificity of various isolates of capripoxvirus. Sequencing several viruses from various geographic regions would potentially allow tracing of the origins of outbreaks and the evolution of capripoxviruses.

\section{Diagnostics for Detection of Capripoxvirus Infection and Characterization of Viruses}

Although skin and visceral pox lesions caused by capripoxviruses are strongly indicative of the diseases in question, a definitive diagnosis requires laboratory confirmation. Classical methods such as electron microscopy can be used to identify capripoxvirus virions in skin lesions (Fig. 2). However, electron microscopy cannot differentiate between SPPV, GTPV and LSDV (Kitching and Smale, 1986). Neither can electron microscopy distinguish capripoxviruses from orthopoxviruses except by the application of specific immunological staining. Orthopoxvirus infections are documented in buffalo and cattle in India (Singh et al., 2007), and cattle in Brazil (Damaso et al., 2000). 


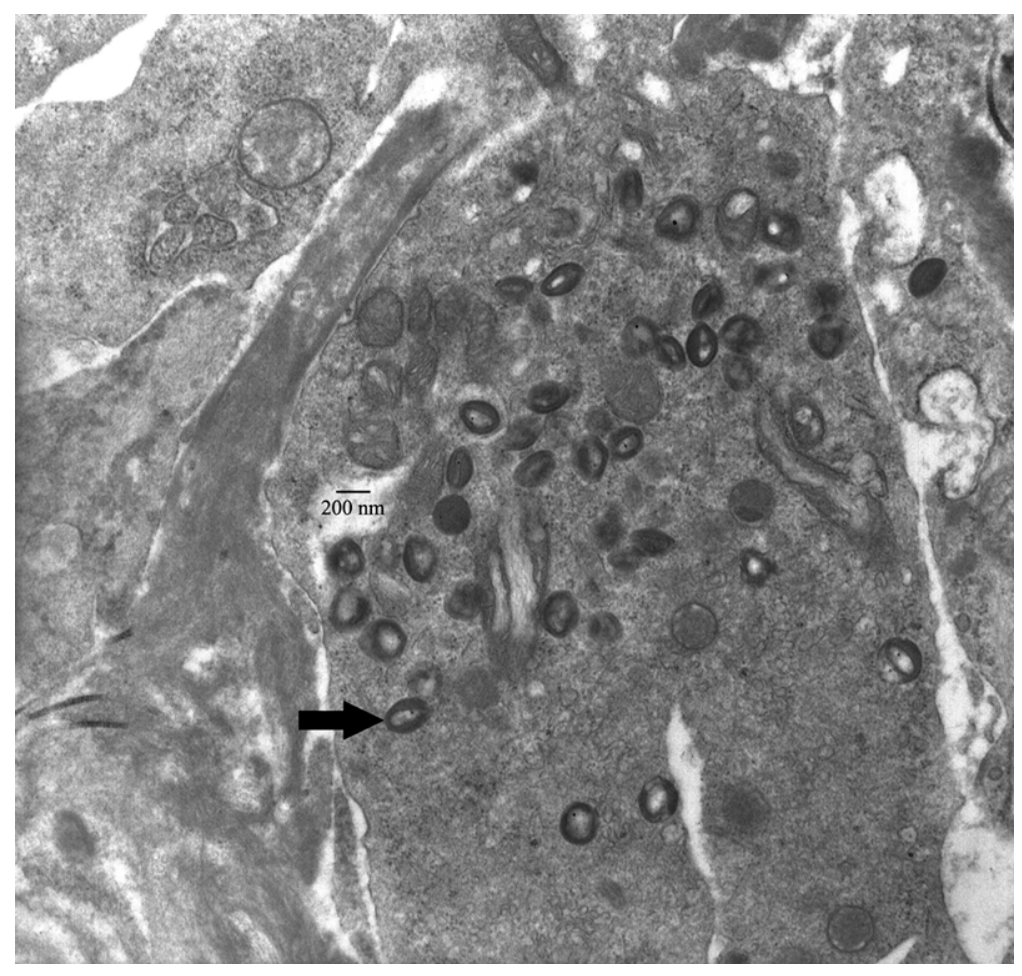

Fig. 2. Capripoxvirus virions from the skin of a capripoxvirus-infected goat. A poxvirus particle is indicated with an arrow.

Knowledge of capripoxvirus pathogenesis demonstrates that skin lesions as well as nasal and oral swabs are the most useful samples for virus isolation (Bowden et al., 2008). Capripoxviruses can be grown using a variety of sheep, goat, and cattle cells (Binepal et al., 2001). Currently, primary lamb kidney or primary lamb testis cells are the most commonly used cells for isolation (Ferris and Plowright, 1958; Kalra and Sharma, 1981; Zhou et al., 2004). They induce the formation of distinct plaques (Soman and Singh, 1980) with a cytopathic effect characterized by elongated cells (Jassim and

Keshavamurthy, 1981). However, primary cells have several disadvantages including the need to constantly establish new cultures, cell lot variation, and contamination with extraneous agents. A lamb testis secondary cell line (OA3.Ts) has been evaluated as a replacement for primary cells (Babiuk et al., 2007). Capripoxvirus isolation can be confirmed by immunostaining using anti-capripoxvirus serum (Gulbahar et al., 2006; Babiuk et al., 2007) but it is not yet possible to differentiate between SPPV, GTPV and LSDV, as there is only a single capripoxvirus serotype (Kitching, 1986). Immunostaining also allows easier visualization of capripoxvirus plaques (Babiuk et al., 2007).

The current gold standard for determining anti-capripoxvirus antibodies is virus neutralization. While effective in detecting anti-capripoxvirus antibodies, it is slow, labour intensive and requires live capripoxvirus, access to which is often not permitted in disease-free countries. A recombinant capripoxvirus that expresses green fluorescent protein (Wallace et al., 2007) is being evaluated for use in a virus neutralization assay 
and has decreased the length of time required for detection of virus neutralization activity from 6 down to 2 days. An immunocapture enzyme-linked immunosorbant assay (ELISA) for detecting capripoxvirus antigen is also reported (Rao et al., 1997). Western blotting assays can be used and are specific and sensitive; however, they are difficult to perform and interpret (Chand et al., 1994). Currently, there is no validated ELISA for the detection of antibodies to SPPV, GTPV or LSDV, despite an earlier report describing the development and preliminary evaluation of a test based on recombinant P32 (Heine et al., 1999), the progress on this assay appears not to have been finalized. Development of a recombinant ELISA is impeded by difficulties in identifying a single immuno-dominant capripoxvirus antigen which is stable and easy to purify. Attempts have been made at using whole inactivated capripoxvirus as an ELISA antigen; however, this was found to be impractical in a routine diagnostic laboratory setup as virus cultivation is too labour intensive and requires bio-containment facilities. It would be a significant advance if the immuno-dominant capripoxvirus antigens were identified and utilized in an ELISA format, with test sensitivity and specificity at least comparable to those of the virus neutralization assay. The duration of the anti-capripoxvirus antibody response is currently unknown, but is likely long-lived, since other poxviruses such as vaccinia virus generate antibody responses detectable years after infection (Hammarlund et al., 2003).

Polymerase chain reaction (PCR) does provide a rapid and sensitive diagnostic technique for capripoxvirus genome detection. Several groups have reported using conventional PCR (Heine et al., 1999; Mangana-Vougiouka et al., 2000) or real-time PCR (Balinsky et al., 2008; Bowden et al., 2008) for detection of capripoxvirus genetic material. The strengths of real-time PCR are its speed, its quantitative nature and the ability to include controls for detection of reaction inhibitors. Despite these benefits, PCR results should be confirmed by at least one additional test. It has been possible to develop a single PCRbased assay to identify all capripoxvirus isolates, and the assay could possibly be refined to be specific only for vaccine isolates (Orlova et al., 2006) or specific for only sheep, goat or cattle isolates if distinct signatures are found. In addition, a PCR assay has been developed to identify both capripoxviruses and orf virus (parapoxvirus) in the same procedure (Zheng et al., 2007).

\section{Vaccines}

Animals that recover from a virulent capripoxvirus infection generate lifelong immunity consisting of both antibody and cellular immunity, which protects the animals from all capripoxvirus isolates (Kitching et al., 1987a). Capripoxvirus infection can be prevented by the administration of anti-capripoxvirus serum (Kitching, 1986), but cell-mediated immunity is likely the most significant component in recovery from infection and in long-term protection, evidenced by the protection afforded by vaccination where the presence of specific antibodies cannot be detected (using existing serological tests). The vaccines currently used against sheeppox, goatpox or LSD in endemic countries are live field isolates (Roth and Spickler, 2003), which have been attenuated by multiple passages in cell culture (Davies and Mbugwa, 1985) and in the chorioallantoic membranes of embryonated hen's eggs (van Rooyen et al., 1969). The Kenyan sheeppox and goatpox 
vaccine (KS-1), an apparently naturally attenuated strain, displays characteristics suggesting that it is intermediate between SPPV, GTPV and LSDV (Kitching et al., 1987a). Some vaccines might be substantially attenuated in one host but too virulent to be used in another. Although most of these live attenuated vaccines work well, reports of vaccine breakdown, short duration of protection, and low levels of antibody inducement necessitate the need for improved vaccines (Hunter and Wallace, 2001). The availability of whole-genome sequence data now allows for a more directed approach to vaccine development by targeting genes specifically involved in virulence and host immune system modulation. A virulent SPPV mutant with a deletion in one of its kelch-like genes was markedly attenuated for virulence in lambs, demonstrating its potential as an experimental vaccine (Balinsky et al., 2007). It is also likely that other genes can be used to attenuate capripoxviruses. Capripoxviruses have been utilized as vectors of other viral genes to elicit protective immune responses to a variety of viral pathogens such as rabies (Aspden et al., 2002), peste des petits ruminants (Diallo et al., 2002), and Rift Valley fever viruses (Wallace et al., 2006). Studies on the viral thymidine kinase (TK) gene of LSDV have shown that TK activity is important for viral growth but, as is the case for many other poxviruses, the gene can be used as an insertion site for the generation of recombinant vaccines (Wallace and Viljoen, 2002). Inevitably, there will be regulatory problems with approving these vaccines in capripoxvirus-free regions, as currently most of these recombinant vaccines do not have the appropriate companion tests available to differentiate infected from vaccinated animals (van Oirschot, 1999). As capripoxviruses are antigenically conserved, a single vaccine can generate long-lasting immunity (Ngichabe et al., 2002) and offer protection in sheep, goats and cattle for all capripoxvirus isolates (Kitching, 2003). Capripoxviruses have a single serotype, do not cause persistent infection, have a limited host range and vaccines are available that provide life-long immunity. These attributes increase the prospect of successfully implementing regional control programs, leading to the elimination of the virus and conceivably global eradication.

\section{Conclusion}

There is a real threat of capripoxviruses spreading into new geographic regions, specifically SPPV and GTPV into south east Asia and LSDV into the Middle East. Spread can occur through trade of infected animals and their products such as wool and hides, as well as through the movement of insect vectors. Naïve animal populations would suffer severe morbidity and mortality. Slaughter of infected and in-contact animals is the current method of choice for eliminating an outbreak in capripoxvirus-free countries. It is critical to develop and validate modern molecular PCR-based assays as well as recombinant protein ELISA tests to enable rapid capripoxvirus diagnostics and surveillance. These tools will increase the capacity to respond to outbreaks, monitor capripoxviruses in endemic regions and study the epidemiology of the diseases.

Eradication of capripoxviruses is possible through vaccination and strict movement control. While progressive control and even regional elimination of infection in areas such as the Maghreb is possibly feasible, the husbandry and social conditions that exist in the Middle East and the Indian subcontinent mitigate against any immediate prospect of 
eradication. Eradication would reduce animal suffering and improve economic development in those usually poor countries in which the virus is endemic. However, the economics of eradication campaigns are likely to be marginal as in many areas small ruminant management involves very small holdings (one to a few animals). In addition, eradication would remove the risk of accidental or deliberate spread to countries free of these viruses.

\section{References}

Achour, H. A., and R. Bouguedour, 1999: Epidemiology of sheep pox in Algeria. Rev. Sci. Tech. 18, 606-617.

Asagba, M. O., and D. R. Nawathe, 1981: Evidence of sheep pox in Nigeria. Trop. Anim. Health Prod. 13, 61.

Aspden, K., A. A. van Dijk, J. Bingham, D. Cox, J. A. Passmore, and A. L. Williamson, 2002: Immunogenicity of a recombinant lumpy skin disease virus (neethling vaccine strain) expressing the rabies virus glycoprotein in cattle. Vaccine. 20, 2693-2701.

Babiuk, S., G. Parkyn, J. Copps, J. E. Larence, M. I. Sabara, T. Bowden, D. B. Boyle, and P. Kitching, 2007: Evaluation of an ovine testes cell line (OA3.Ts) for use in the propagation and detection of capripox virus and development of immunostaining technique for viral plaque visualization. J.Vet. Diagn. Invest. 5, 486-491.

Balinsky, C. A., G. Delhon, C. L. Afonso, G. R. Risatti, M. V. Borca, R. A. French, E. R. Tulman, S. J. Geary, and D. L. Rock, 2007: Sheeppox virus kelch-like gene SPPV-019 affects virus virulence. J. Virol. 81, 11392-11401.

Balinsky, C. A., G. Delhon, G. Smoliga, M. Prarat, R. A. French, S. J. Geary, D. L. Rock, and L. L. Rodriguez, 2008: Rapid preclinical detection of sheeppox virus by a real-time PCR assay. J. Clin. Microbiol. 46, 438-442.

Bhanuprakash, V., A. R. Moorthy, G. Krishnappa, R. N. Srinivasa Gowda, and B. K. Indrani, 2005: An epidemiological study of sheep pox infection in Karnataka State, India. Rev. Sci. Tech. 24, 909-920.

Bhanuprakash, V., B. K. Indrani, M. Hosamani, and R. K. Singh, 2006: The current status of sheep pox disease. Comp. Immunol. Microbiol. Infect. Dis. 29, 27-60.

Binepal, Y. S., F. A. Ongadi, and J. C. Chepkwony, 2001: Alternative cell lines for the propagation of lumpy skin disease virus. Onderstepoort J. Vet. Res. 68, 151-153.

Bowden, T. R., S. L. Babiuk, G. R. Parkyn, J. S. Copps, and D. B. Boyle, 2008:

Capripoxvirus tissue tropism and shedding: A quantitative study in experimentally infected sheep and goats. Virol. 371, 380-393. 
Buller, R. M., B. M. Arif, D. N. Black, K. R. Dumbell, J. J. Esposito, E. J. Lefkowitz, G. McFadden, B. Moss, A. A. Mercer, R. W. Moyer, M. A. Skinner, and D. N. Tripathy, 2005: Family Poxviridae. In: Fauquet, C. M., M. A. Mayo, J. Maniloff, U. Desselberger, and L. A. Ball (eds), Virus Taxonomy: Classification and Nomenclature of Viruses. Eighth Report of the International Committee on Taxonomy of Viruses, pp. 117-133. Elsevier Academic Press, San Diego.

Carn, V. M., 1993: Control of capripoxvirus infections. Vaccine. 11, 1275-1279. Carn, V. M., and R. P. Kitching, 1995a: The clinical response of cattle experimentally infected with lumpy skin disease (Neethling) virus. Arch. Virol. 140, 503-513.

Carn, V. M., and R. P. Kitching, 1995b: An investigation of possible routes of transmission of lumpy skin disease virus (Neethling). Epidemiol. Infect. 114, 219-226.

Chand, P., R. P. Kitching, and D. N. Black, 1994: Western blot analysis of virus-specific antibody responses to capripoxvirus and contagious pustular dermatitis infections in sheep. Epidemiol. Infect. 113, 377-385.

Chihota, C. M., L. F. Rennie, R. P. Kitching, and P. S. Mellor, 2001: Mechanical transmission of lumpy skin disease virus by Aedes aegypti (Diptera: Culicidae). Epidemiol. Infect. 126, 317-321.

Chihota, C. M., L. F. Rennie, R. P. Kitching, and P. S. Mellor, 2003: Attempted mechanical transmission of lumpy skin disease virus by biting insects. Med. Vet. Entomol. 17, 294-300.

Damaso, C. R., J. J. Esposito, R. C. Condit, and N. Moussatché, 2000: An emergent poxvirus from humans and cattle in Rio de Janeiro State: Cantagalo virus may derive from Brazilian smallpox vaccine. Vir. 277, 439-449.

Damon, I. K., 2007: Poxviruses. In: Knipe, D. M., P. M. Howley, D. E. Griffin, R. A. Lamb, M. A. Martin, B. Roizman, and S. E. Straus (eds), Fields Virology, pp. 29472975. Lippincott Williams \& Wilkins, Philadelphia.

Daoud, J. A., 1997: Sheep pox among Australian sheep in Jordan. Trop. Anim. Health Prod. 29, 251-252.

Davies, F. G., 1976: Characteristics of a virus causing a pox disease in sheep and goats in Kenya, with observation on the epidemiology and control. J. Hyg. (Lond). 76, 163-171.

Davies, F. G., 1982: Observations on the epidemiology of lumpy skin disease in Kenya. $J$ Hyg. (Cambridge). 88, 95-102.

Davies, F. G., 1991: Lumpy skin disease, an African capripox virus disease of cattle. Br. Vet. J. 147, 489-503. 
Davies, F. G., and G. Mbugwa, 1985: The alterations in pathogenicity and immunogenicity of a Kenya sheep and goat pox virus on serial passage in bovine foetal muscle cell cultures. J. Comp. Pathol. 95, 565-572.

De Clercq, K., and N. Goris, 2004: Extending the foot-and-mouth disease module to the control of other diseases. Dev. Biol. (Basel). 119, 333-340.

Diallo, A., and G. J. Viljoen, 2007: Genus Capripoxvirus. In: Mercer, A. A., A. Schmidt, and O. Weber (eds), Poxviruses, pp. 167-181. Birkhäuser, Basel, Switzerland.

Diallo, A., C. Minet, G. Berhe, C. Le Goff, D. N. Black, M. Fleming, T. Barrett, C. Grillet, and G. Libeau, 2002: Goat immune response to capripox vaccine expressing the hemagglutinin protein of peste des petits ruminants. Ann. NY Acad. Sci. 969, 88-91.

Diesel, A. M., 1949: The epizootiology of lumpy skin disease in South Africa. Proc 14th Int Vet Congr. Lond., 2, 492-500.

Domenech, J., J. Lubroth, C. Eddi, V. Martin, and F. Roger, 2006: Regional and international approaches on prevention and control of animal transboundary and emerging diseases. Ann. NY Acad. Sci. 1081, 90-107.

Fenner, F. M., F. Day, and G. M. Woodroofe, 1952: The mechanism of the transmission of myxomatosis in the European rabbit (Oryctolagus cuniculus) by the mosquito Aedes aegypti. Aust. J. Exp. Biol. Med. Sci. 30, 139-152.

Ferris, R. D., and W. Plowright, 1958: Simplified methods for the production of monolayers of testis cells from domestic animals, and for serial examination of monolayer cultures. J. Path. Bact. 75, 313-318.

Garner, M. G., and M. B. Lack, 1995: Modelling the potential impact of exotic diseases on regional Australia, Aust. Vet. J. 72, 81-87.

Garner, M. G., S. D. Sawarkar, E. K. Brett, J. R. Edwards, V. B. Kulkarni, D. B. Boyle, and S. N. Singh, 2000: The extent and impact of sheep pox and goat pox in the state of Maharashtra, India. Trop. Anim. Health Prod. 32, 205-223.

Greth, A., J. M. Gourreau, M. Vassart, ??. Nguyen-Ba-Vy, M. Wyers, and P. C. Lefevre, 1992a: Capripoxvirus disease in an Arabian oryx (Oryx leucoryx) from Saudi Arabia. J. Wildl. Dis. 28, 295-300.

Greth, A., D. Calvez, M. Vassart, and P. C. Lefèvre, 1992b: Serological survey for bovine bacterial and viral pathogens in captive Arabian oryx (Oryx leucoryx Pallas, 1776). Rev. Sci. Tech. 11, 1163-1168.

Gulbahar, M. Y., W. C. Davis, H. Yuksel, and M. Cabalar, 2006: Immunohistochemical 
evaluation of inflammatory infiltrate in the skin and lung of lambs naturally infected with sheeppox virus. Vet. Pathol. 43, 67-75.

Hammarlund, E., M. W. Lewis, S. G. Hansen, L. I. Strelow, J. A. Nelson, G. J. Sexton, J. M. Hanifin, and M. K. Slifka, 2003: Duration of antiviral immunity after smallpox vaccination. Nat. Med. 9, 1131-1137.

Hedger, R. S., and C. Hamblin, 1983: Neutralising antibodies to lumpy skin disease virus in African wildlife. Comp. Immunol. Microbiol. Infect. Dis. 6, 209-213.

Heine, H. G., M. P. Stevens, A. J. Foord, and D. B. Boyle, 1999: A capripoxvirus detection PCR and antibody ELISA based on the major antigen P32, the homolog of the vaccinia virus H3L gene. J. Immunol. Methods 227, 187-196.

Hosamani, M., B. Mondal, P. A. Tembhurne, S. K. Bandyopadhyay, R. K. Singh, and T. J. Rasool, 2004: Differentiation of sheep pox and goat poxviruses by sequence analysis and PCR-RFLP of P32 gene. Virus Genes 29, 73-80.

House, J. A., T. M. Wilson, S. el Nakashly, I. A. Karim, I. Ismail, N. el Danaf, A. M. Moussa, and N. N. Ayoub, 1990: The isolation of lumpy skin disease virus and bovine herpesvirus-4 from cattle in Egypt. J. Vet. Diagn. Invest. 2, 111-115.

Hunter, P., and D. Wallace, 2001: Lumpy skin disease in southern Africa: a review of the disease and aspects of control. J. South Afr. Vet. Assoc. 72, 68-71.

Irons, P. C., E. S. Tuppurainen, and E. H. Venter, 2005: Excretion of lumpy skin disease virus in bull semen. Theriogenology. 63, 1290-1297.

Jassim, F. A., and B. S. Keshavamurthy, 1981: Cytopathic changes caused by sheep pox virus in secondary culture of lamb testes cells. Bull. Off. Int. Epiz. 93, 1401-1410.

Kalra, S. K., and V. K. Sharma, 1981: Adaptation of Jaipur strain of sheeppox virus in primary lamb testicular cell culture. Indian J. Exp. Biol. 19, 165-169.

Kara, P. D., C. L. Afonso, D. B. Wallace, G. F. Kutish, C. Abolnik, Z. Lu, F. T Vreede, L. C. Taljaard, A. Zsak, G. J. Viljoen, and D. L. Rock, 2003: Comparative sequence analysis of the South African vaccine strain and two virulent field isolates of Lumpy skin disease virus. Arch. Virol. 148, 1335-1356.

Kitching, R. P., 1986: Passive protection of sheep against capripoxvirus. Res. Vet. Sci. 41, 247-250.

Kitching, R. P., 2003: Vaccines for lumpy skin disease, sheep pox and goat pox. Dev. Biol. (Basel) 114, 161-167.

Kitching, R. P., and V. M. Carn, 2004: Sheep pox and goat pox. Office International des 
Epizooties Manual of Diagnostic Tests and Vaccines for Terrestrial Animals (mammals, birds and bees). OIE, Paris.

Kitching, R. P., and C. Smale, 1986: Comparison of the external dimensions of capripoxvirus isolates. Res. Vet. Sci. 41, 425-427.

Kitching, R. P., and W. P. Taylor, 1985: Clinical and antigenic relationship between isolates of sheep and goat pox viruses. Trop. Anim. Health Prod. 17, 64-74.

Kitching, R. P., J. J. McGrane, and W. P. Taylor, 1986: Capripox in the Yemen Arab Republic and the Sultanate of Oman. Trop. Anim. Health Prod. 18, 115-122.

Kitching, R. P., J. M. Hammond, and W. P. Taylor, 1987a: A single vaccine for the control of capripox infection in sheep and goats. Res. Vet. Sci. 42, 53-60.

Kitching, R. P., J. J. McGrane, J. M. Hammond, A. H. Miah, A. H. Mustafa, and J. R. Majumder, 1987b: Capripox in Bangladesh. Trop. Anim. Health Prod. 19, 203-208.

Kitching, R. P., P. P. Bhat, and D. N. Black, 1989: The characterization of African strains of capripoxvirus. Epidemiol. Infect. 102, 335-343.

Mangana-Vougiouka, O., P. Markoulatos, G. Koptopoulos, K. Nomikou, N.

Bakandritsos, and P. Papadopoulos, 2000: Sheep poxvirus identification from clinical specimens by PCR, cell culture, immunofluorescence and agar gel immunoprecipitation assay. Mol. Cell. Probes 14, 305-310.

Mariner, J. C., J. A. House, T. M. Wilson, M. van den Ende M, and I. Diallo, 1991:

Isolation of sheep pox virus from a lamb in Niger. Trop. Anim. Health Prod. 23, 27-28.

McFadden, G., 2005: Poxvirus tropism. Nat. Rev. Microbiol. 3, 201-213.

Mellor, P. S., R. P. Kitching, and P. J. Wilkinson, 1987: Mechanical transmission of capripox virus and African swine fever virus by Stomoxys calcitrans. Res. Vet. Sci. 43, 109-112.

Mondal, B., M. Hosamani, T. K. Dutta, V. S. Senthilkumar, Rathore. R., and R. K. Singh, 2004: An outbreak of sheep pox on a sheep breeding farm in Jammu, India. Rev. Sci. Tech. 23, 943-949.

Moss, B., 2006: Poxvirus entry and membrane fusion. Virology 344, 48-54.

Moss, B., and J. L. Shisler, 2001: Immunology 101 at poxvirus U: immune evasion genes. Semin. Immunol. 13, 59-66.

Ngichabe, C. K., H. M. Wamwayi, E. K. Ndungu, P. K. Mirangi, C. J. Bostock, D. N. Black, and T. Barrett, 2002: Long term immunity in African cattle vaccinated with a 
recombinant capripox-rinderpest virus vaccine. Epidemiol. Infect. 128, 343-349.

Oğuzoğlu, T. C., F. Alkan, A. Ozkul, S. A. Vural, A. B. Güngör, and I. Burgu, 2006: A sheeppox virus outbreak in central Turkey in 2003: isolation and identification of capripoxvirus ovis. Vet. Res. Commun. 30, 965-971.

van Oirschot, J. T., 1999: Diva vaccines that reduce virus transmission. J. Biotechnol. 73, 95-205.

Orlova, E. S., A. V. Shcherbakova, V. I. Diev, and V. M. Zakharov, 2006: Differentiation of capripoxvirus species and strains by polymerase chain reaction. Mol. Biol. (Mosk). 40, $158-164$.

Osuagwuh, U. I., V. Bagla, E. H. Venter, C. H. Annandale, and P. C. Irons, 2007:

Absence of lumpy skin disease virus in semen of vaccinated bulls following vaccination and subsequent experimental infection. Vaccine 25, 2238-2243.

Rao, T. V., P. Malik, S. Nandi, and B. S. Negi, 1997: Evaluation of immunocapture ELISA for diagnosis of goat pox. Acta Virol. 41, 345-348.

Regnery, R. L., 2007: Poxviruses and the passive quest for novel hosts. Curr. Top. Microbiol. Immunol. 315, 345-361.

Van Rooyen, P. J., E. K. Munz, and K. E. Weiss, 1969: The optimal conditions for the multiplication of Neethling-type LSDV in embryonated eggs. Onderstepoort J. Vet. Res. 36, 165-174.

Roth, J. A., and A. R. Spickler, 2003: A survey of vaccines produced for OIE list A diseases in OIE member countries. Dev. Biol. (Basel). 114, 5-25.

Rweyemamu, M., R. Paskin, A. Benkirane, V. Martin, P. Roeder, and K. Wojciechowski, 2000: Emerging diseases of Africa and the Middle East. Ann. NY Acad. Sci. 916, 61-70.

Singh, R. K., M. Hosamani, V. Balamurugan, V. Bhanuprakash, T. J. Rasool, and M. P. Yadav, 2007: Buffalopox: an emerging and re-emerging zoonosis. Anim. Health. Res. Rev. 8, 105-114.

Soman, J. P., and I. P. Singh, 1980: Plaque formation by sheep pox virus adapted to lamb kidney cell culture. Indian J. Exp. Biol. 18, 313-314.

Stanford, M. M., G. McFadden, G. Karupiah, and G. Chaudhri, 2007:

Immunopathogenesis of poxvirus infections: forecasting the impending storm. Immunol. Cell Biol. 85, 93-102.

Tulman, E. R., C. L. Afonso, Z. Lu, L. Zsak, G. F. Kutish, and D. L. Rock, 2001:

Genome of lumpy skin disease virus. J. Virol. 75, 7122-7130. 
Tulman, E. R., C. L. Afonso, Z. Lu, L. Zsak, J. H. Sur, N. T. Sandybaev, U. Z. Kerembekova, V. L. Zaitsev, G. F. Kutish, and D. L. Rock, 2002: The genomes of sheeppox and goatpox viruses. J. Virol. 76, 6054-6061.

Wallace, D. B., and G. J. Viljoen, 2002: Importance of thymidine kinase activity for normal growth of lumpy skin disease virus (SA-Neethling). Arch. Virol. 147, 659-663.

Wallace, D. B., C. E. Ellis, A. Espach, S. J. Smith, R. R. Greyling, and G. J. Viljoen, 2006: Protective immune responses induced by different recombinant vaccine regimes to Rift Valley fever. Vaccine 24, 7181-7189.

Wallace, D. B., J. Weyer, L. H. Nel, and G. J. Viljoen, 2007: Improved method for the generation and selection of homogeneous lumpy skin disease virus (SA-Neethling) recombinants. J. Virol. Methods 146, 52-60.

Woods, J. A., 1988: Lumpy skin disease--a review. Trop. Anim. Health Prod. 20, 1117.

Yeruham, I., O. Nir, Y. Braverman, M. Davidson, H. Grinstein, M. Haymovitch, and O. Zamir, 1995: Spread of lumpy skin disease in Israeli dairy herds. Vet. Rec. 137, 91-93.

Yeruham, I., H. Yadin, M. Van Ham, V. Bumbarov, A. Soham, and S. Perl, 2007:

Economic and epidemiological aspects of an outbreak of sheeppox in a dairy sheep flock. Vet. Rec. 160, 236-237.

Young, E., P. A. Basson, and K. E. Weiss, 1970: Experimental infection of game animals with lumpy skin disease virus (prototype strain Neethling).Onderstepoort J. Vet. Res. 37, 79-87.

Zheng, M., Q. Liu, N. Jin, J. Guo, X. Huang, H. Li, W. Zhu, and Y. Xiong, 2007: A duplex PCR assay for simultaneous detection and differentiation of Capripoxvirus and Orf virus. Mol. Cell. Probes 21, 276-281.

Zhou, J. S., H. L. Ma, and Q. S. Guo, 2004: Culturing of ovine testicular cells and observation of pathological changes of the cell inoculated with attenuated sheep pox virus. Chinese J. Vet. Sci. Technol. 34, 71-74. 